\title{
NGAJI SOSMED TANGKAL PEMAHAMAN RADIKAL MELALUI PENDAMPINGAN KOMUNITAS LANSIA DENGAN SAJIAN PROGRAM NGABARI DI DESA SUKOREJO SUKOWONO JEMBER
}

\author{
Hosaini \\ Universitas Bondowoso, Indonesia \\ hosaini2612@gmail.com
}

\begin{abstract}
This outreach program is carried out in Sukurejo village in Sukowono, Jember with an agrarian society. The method used is the location survey. They are finding out the problems experienced by the community to local community leaders and submitting proposals, involving students or members of the team, coaching and planning the implementation of "NGABARI", gathering communities who will be members of assistance, planning programs that will be implemented as the solution of solving the problems experienced by the community. determine the time and deliver students or teams to the location, collaborate with community leaders to carry out the planned "NGABARI" program, carry out monitoring and evaluation midway through the implementation of activities, monitoring and evaluation at the end of the month because the ngabari program is carried out once a week. The results obtained are an increase in the competence of community religious learning and be able to align community understanding that is contradictory to the essence of Islamic religious learning in a basic way. Radical religious ideology caused by social media can be tipped with the "NGABARI" program activities.
\end{abstract}

Keywords: Ngaji Sosmed, Pemahaman Radikal 


\section{Latar Belakang}

Masyarakat Desa Sukurejo Sukowono Jember adalah masyarakat yang masih tergolong Agraris dalam artian masyaraktat agraris merupakan masyarakan yang bergerak disektor pertaniaan atau penduduk mayoritas mata pencahariannya dibidang sektor Pertanian, Pola hidup masyarakat dimasing-masing Desa Memang berbeda-beda. Dimensi kehidupan Masyarakat Ada 3 a. Masyarakat Dinamis b. Masyarakat Agraris dan c. Masyarakat Pesisir, seperti apapun intensitas dan kondisi Masyarakat adalah kehidupan yang bersifat Sunnatullah, namun Masyarakat Yang baik adalah Masyarakat yang memiliki pola kehidupan yang harmonis mempunyai Sifat Toleransi cinta Tanah Air, memiliki Sifat Nasionalisme, simpati dan empati terhadap Sesama,

Dalam UUD No. 28 tahun 2006 disebutkan tentang Fungsi dan Tujuan Bela Negara diantaranya adalah Mempertahankan Kelangsungan Hidup bangsa dan Negara, melestarikan Budaya Dan menjalankan Nilai-Nilai Pancasila dan UUD 1945. Mengingat pernyataan Undang-undang tersebut Bahwa Masyarakat mempunyai Peran penting Untuk menjalankan Pola kehidupannya dengan Berpegang Teguh Pada UUD 1945 dan Menanamkan Nilai-Nilai Pancasila Dalam kehidupan Sehar-hari. Selain Itu Aliran Masyarakat 
menjadi ciri khas pada setiap karakter masyarakat Secara Umum, tak sedikit diantara masyarakat menyadari bahwa, kudrat dari kehidupan berbudaya dan bersuku-suku adalah karakter kehidupan Masyarakat yang ada di negara Indonesia Sehingga akibat dari ketidak Fahaman masyarakat Tersebut, Maka Masyarat Cendurung Memiliki Sikap Radikalisme dan Intoleran terhadap Sesama, ${ }^{1}$

Oleh Karena itu, Kami sebagai Pendidik ditingkat Perguruan Tinggi memiliki Tugas pokok yang sangat Urgen sebagai pelaksana Tridharma perguruan Tinggi diantaranya Adalah melaksanakan Pengabdian kepada Masyarakat. UU permendikti 44 tahun 2015 pasal 55-63 menjelaskan tentang pengabdian kepada masyarakat yang harus diselenggarakan disetiap Perguruan Tinggi. dan dilaksanakan oleh setiap Dosen ,

Kondisi Masyarakat Sukorejo Sukowono Jember saat ini merupakan Masyarakat yang pola kehidupannya sebagian, memiliki pola fikir atau maensed Radikal, dalam Persoalan Dokmatis Agama (Agama Islam) pada setiap persepsinya, selalu membenarkan dirinya sendiri, dan cenderung menyalahkan Orang lain, Penyebabnya adalah a. kebiasaan Masyarakat tersebut Cendurung mengadopsi ajaran Agama

1 UUD No. 28 Tahun 2006 
Islam Pada You Tube sehingga apa yang didapatkan pada pembahasan/pembelajaran di You Tube Tersebut Masyarakat menyimpulakan sendiri dan dijadikan dasar dalam kehidupan seharihari b. Menyalahkan diri sendiri Bahwa dalam beribadah tidak ada gunanya. Menyikapi peristiwa tersebut maka kami merasa terpanggil untuk mengumpulkan masyarakat Sukorejo Sukowono Jember untuk memberikan arahan dan pembelajaran yang sesuai dengan Dogmatis Agama islam yang berlandaskan Ahlusunnah Waljama'ah, bentuk pembelajaran yang akan kami ajikan adalah Tuntunan pembelajaran Agama islam (islam Moderat) yang dikemas dengan Program “NGABARI" ngaji Bareng Abi di Pondok Pesantren AL Mulk Sukorejo Sukowono Jember.

\section{Rumusan Masalah}

Dari penjelasan yang tertera dilatar Belakang tersebut maka Pelaksana Pengabdian Kepada Masyarakat dapat merumuskan permasalahan sebagai Berikut:

a. Apa yang menyebabkan Masyarakat cenderung memiliki pola fikir dan Sikap radikal

b. Bagaimana Mengatasi masyarakat yang pola fikirnya Radikal 
c. apa saja Faktor penghambat dan pendukung dalam melaksanakan pengabdian Kepada Masyarakat

\section{Tujuan Pengabdian}

a. Memberikan Pemahaman Kepada Masyarakat tentang pembelajaran Agama islam yang baik dan benar

b. Memberikan Pendampingan Kepada Masyarakat supaya dalam mengadopsi pembelajaran agama tidak bersifat Rational Jumping

c. Untuk mengatasi pola fikir masyarakat yang radikal maka perlu pendampingan dalam pembelajaran agama islam sebagai dasar kehidupan Masyarakat Sehari-hari

d. Mampu membentuk pola fikir masyarakat yang dinamis brdasarkan ajaran Dogmatis Agama islam Moderat

\section{Kajian Pengabdian Terdahulu Yang Relevan}

\begin{tabular}{|c|l|l|l|l|}
\hline No & $\begin{array}{c}\text { Nama } \\
\text { Pelaksana } \\
\text { PKM }\end{array}$ & \multicolumn{1}{|c|}{ Judul PKM } & Relevasi kajian & Hasil \\
\hline 1 & $\begin{array}{l}\text { Taufiqurrah } \\
\text { man, } \\
\text { Mahmudi }\end{array}$ & $\begin{array}{l}\text { Pelatihan } \\
\text { Khotib dan Bilal } \\
\text { bagi remaja }\end{array}$ & $\begin{array}{l}\text { Kegiatan } \\
\text { pengabdian ini } \\
\text { memiliki relevasi }\end{array}$ & $\begin{array}{l}\text { Hasil dalam } \\
\text { pelaksnaan } \\
\text { Pengabdian }\end{array}$ \\
\hline
\end{tabular}




\begin{tabular}{|c|c|c|c|c|}
\hline No & $\begin{array}{c}\text { Nama } \\
\text { Pelaksana } \\
\text { PKM }\end{array}$ & Judul PKM & Relevasi kajian & Hasil \\
\hline & $\begin{array}{l}\text { Nur } \\
\text { qonsyah² }\end{array}$ & $\begin{array}{l}\text { dikecamatan } \\
\text { Muara uya } \\
\text { Kabuten } \\
\text { Tabalong }\end{array}$ & $\begin{array}{l}\text { terhadap } \\
\text { penyajian/tema } \\
\text { permaslahan yang } \\
\text { telah kami kaji } \\
\text { sesuai dengan } \\
\text { kondisi dan } \\
\text { Situasi masyarakat } \\
\text { yang berada } \\
\text { ditempat sasaran, } \\
\text { sebagai mana } \\
\text { dikutib dalam } \\
\text { tema yang } \\
\text { disajikan Oleh } \\
\text { Taufiqurrahman } \\
\text { DKK dalam } \\
\text { pengabdiannya" } \\
\text { menyatakan } \\
\text { bahwa } \\
\text { pendampingan } \\
\text { kepada } \\
\text { Masyarakat } \\
\text { dengan tujuan } \\
\text { untuk }\end{array}$ & $\begin{array}{l}\text { yang } \\
\text { dilaksanaka } \\
\text { n Oleh } \\
\text { Taufiqurrah } \\
\text { man DKK. } \\
\text { Adalah } \\
\text { sebagai } \\
\text { berikut } \\
\text { 1. Masyara } \\
\text { kat } \\
\text { dalam } \\
\text { melaksna } \\
\text { kan } \\
\text { ibadah } \\
\text { sholat } \\
\text { jum'at } \\
\text { dilaksan } \\
\text { akn } \\
\text { dengan } \\
\text { baik dan } \\
\text { benar } \\
\text { secara } \\
\text { tuntunan }\end{array}$ \\
\hline
\end{tabular}

2Taufiqurrahamn DKK. Laporan Kegiatan Pengabdian Kepada Masyarakat "pelatihan khotib dan Bilal dikecamatan Uya Kabupaten tabalong 2014 


\begin{tabular}{|c|c|c|c|c|}
\hline No & $\begin{array}{c}\text { Nama } \\
\text { Pelaksana } \\
\text { PKM }\end{array}$ & Judul PKM & Relevasi kajian & Hasil \\
\hline & & & $\begin{array}{l}\text { memberikan sajian } \\
\text { berupa } \\
\text { pembelajaran } \\
\text { agama islam } \\
\text { dibidang ilmu } \\
\text { fiqih yang dalam } \\
\text { hal inisub tema } \\
\text { yang diambil } \\
\text { adalah Tentang } \\
\text { Pembelajaran Bilal } \\
\text { dan Khatib, tujuan } \\
\text { pelaksanaan } \\
\text { Kegiatan ini } \\
\text { adalah untuk } \\
\text { mencerdasakan } \\
\text { Masyarakat } \\
\text { supaya memiliki } \\
\text { pengetahuan } \\
\text { dalam } \\
\text { pelaksanaan } \\
\text { kegiatan } \\
\text { keagamaan } \\
\text { sebagai kegiatan } \\
\text { rutinitas sehari- } \\
\text { hari yaitu } \\
\text { melaksanakan } \\
\text { sholat jum'at }\end{array}$ & $\begin{array}{l}\text { 2. Peari'at } \\
\text { an bilal } \\
\text { dan } \\
\text { khotib } \\
\text { yang } \\
\text { dilakuka } \\
\text { n oleh } \\
\text { masyara } \\
\text { kat } \\
\text { adalah } \\
\text { sesuai } \\
\text { dengan } \\
\text { tuntuna } \\
\text { Dogmati } \\
\text { s agama } \\
\text { sebagai } \\
\text { dasar } \\
\text { dan } \\
\text { acuan } \\
\text { sehingga } \\
\text { masyara } \\
\text { kat yang } \\
\text { satu } \\
\text { dengan } \\
\text { yang } \\
\text { lainnya }\end{array}$ \\
\hline
\end{tabular}




\begin{tabular}{|c|c|c|c|c|}
\hline No & $\begin{array}{c}\text { Nama } \\
\text { Pelaksana } \\
\text { PKM }\end{array}$ & Judul PKM & Relevasi kajian & Hasil \\
\hline & & & $\begin{array}{l}\text { secara berjama'ah } \\
\text { yang diawali } \\
\text { dengan } \\
\text { pembacaan bilal } \\
\text { dan disertai } \\
\text { dengan khotib, } \\
\text { oleh karnanya } \\
\text { dengan peltihan } \\
\text { ini sekiranya bisa } \\
\text { memberikan } \\
\text { pemahaman dan } \\
\text { pengetahuan } \\
\text { kepada } \\
\text { Masyarakat } \\
\text { bagaimana meiliki } \\
\text { pengetahuan } \\
\text { dalam } \\
\text { melaksanakan } \\
\text { ibadah dengan } \\
\text { baik dan benar } \\
\text { sesuai dengan } \\
\text { tuntunan syariat } \\
\text { dan tidak mudah } \\
\text { menyalahkan } \\
\text { orang lain. }\end{array}$ & $\begin{array}{l}\text { Tidak } \\
\text { Mudah } \\
\text { menyala } \\
\text { hkan dan } \\
\text { member } \\
\text { narkan } \\
\text { diri } \\
\text { sendiri } \\
\text { 3. Pengetah } \\
\text { uan } \\
\text { tentang } \\
\text { khitib } \\
\text { dan bilal } \\
\text { menjadi } \\
\text { meningk } \\
\text { at } \\
\text { Kesimpulan. } \\
\text {. dalam } \\
\text { pelaksanaan } \\
\text { Pengabdian } \\
\text { yang } \\
\text { dilaksnaaka } \\
\text { n oleh } \\
\text { Taufiq dkk. } \\
\text { Perlu tindak } \\
\text { lanjut, dan } \\
\text { penelitian }\end{array}$ \\
\hline
\end{tabular}




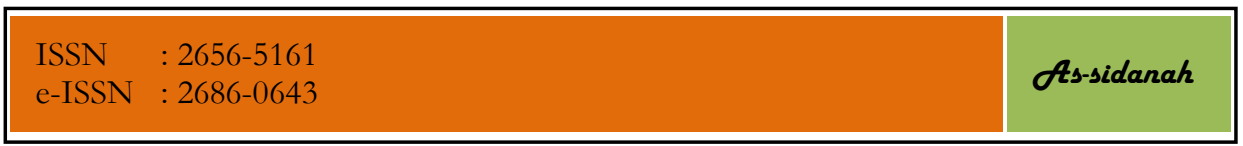

\begin{tabular}{|c|c|c|c|c|}
\hline No & $\begin{array}{c}\text { Nama } \\
\text { Pelaksana } \\
\text { PKM }\end{array}$ & Judul PKM & Relevasi kajian & Hasil \\
\hline & & & & $\begin{array}{l}\text { ini belum } \\
\text { menumuka } \\
\mathrm{n} \text { hasil yang } \\
\text { fantantis } \\
\text { karna } \\
\text { objektifitas } \\
\text { pengkajiann } \\
\text { ya masih } \\
\text { bersifat } \\
\text { khusus } \\
\text { pada satu } \\
\text { segmen } \\
\text { pembahasan }\end{array}$ \\
\hline 2 & SUNARIMO & $\begin{array}{l}\text { Pendampingan } \\
\text { Forum } \\
\text { komonikasi } \\
\text { Pendidikan Al } \\
\text { Qur'an ( dalam } \\
\text { pembinaan } \\
\text { Taman } \\
\text { Pendidikan Al } \\
\text { Qur'an) }{ }^{3} \text { di } \\
\text { desa randu sari } \\
\text { (Tujuannya }^{\text {Tujuan }}\end{array}$ & $\begin{array}{l}\text { Dalam PKM yang } \\
\text { dilaksna Oleh } \\
\text { "Sunarmo" } \\
\text { menjelakan } \\
\text { tentang Lembaga } \\
\text { Pembelajaran } \\
\text { Pembinaan Al } \\
\text { Qur'an adalah } \\
\text { yang mempunyai } \\
\text { perana Strategis } \\
\text { Untuk dalam }\end{array}$ & $\begin{array}{l}\text { PKM yang } \\
\text { dilaksanaka } \\
\text { n Oleh } \\
\text { saudara } \\
\text { "Sunarmo" } \\
\text { adalah } \\
\text { bertujuna } \\
\text { Untuk } \\
\text { memberikan } \\
\text { pengetahua } \\
\text { n kepada }\end{array}$ \\
\hline
\end{tabular}

${ }^{3}$ Sunarimo. Pendampingan Forum komonikasi Pendidikan Al Qur'an ( dalam pembinaan Taman Pendidikan Al Qur'an) 2011 


\begin{tabular}{|c|c|c|c|c|}
\hline No & $\begin{array}{c}\text { Nama } \\
\text { Pelaksana } \\
\text { PKM }\end{array}$ & Judul PKM & Relevasi kajian & Hasil \\
\hline & & $\begin{array}{l}\text { ialah untuk } \\
\text { meningkatkan } \\
\text { pemahaman } \\
\text { Masyarakat } \\
\text { terhadap Ilmu } \\
\text { Al Qur'an } \\
\text { Terampil } \\
\text { Membaca, } \\
\text { mengamalkan } \\
\text { dengan baik } \\
\text { dan benar } \\
\text { sesuai dengan } \\
\text { Tuntunan } \\
\text { Syari'at islam } \\
\text { yang } \\
\text { berlandaskan Al } \\
\text { Qur'an Dan } \\
\text { Hadist }\end{array}$ & $\begin{array}{l}\text { Pembinaan TPA di } \\
\text { Randu Sari yaitu } \\
\text { sebagai } \\
\text { kordinator, } \\
\text { komonikator, dan } \\
\text { Lembaga Da'wah } \\
\text { dalam } \\
\text { Pembelajaran Al } \\
\text { Qur'an, } \\
\text { “sedangkan } \\
\text { langkah } \\
\text { pembinaan TPA } \\
\text { yang ditempuh } \\
\text { Oleh FKPA yang } \\
\text { pertama adalah } \\
\text { melalui } \\
\text { pembinaan Para } \\
\text { pengasuh TPA } \\
\text { sebagai salah satu } \\
\text { masyarakat } \\
\text { sekaligus sebagai } \\
\text { Guru TPA, maka } \\
\text { perlu } \\
\text { pendampinga } \\
\text { dalam } \\
\text { melaksnakan } \\
\text { sistem }\end{array}$ & $\begin{array}{l}\text { Masyarakat } \\
\text { yang ada di } \\
\text { Desa Randu } \\
\text { Sari supaya } \\
\text { meiliki } \\
\text { pemahaman } \\
\text { dibidang } \\
\text { Ilmu Al } \\
\text { Qur'an, } \\
\text { bagaiaman } \\
\text { Masyarakat } \\
\text { dan } \\
\text { generasi } \\
\text { Melinial } \\
\text { mampu } \\
\text { memahami } \\
\text { dan } \\
\text { membaca al } \\
\text { Qur'an } \\
\text { dengan Baik } \\
\text { sesuai } \\
\text { dengan } \\
\text { Tuntunan } \\
\text { Ilmu } \\
\text { Tajwidnya, } \\
\text { Adapun } \\
\text { Pembelajara }\end{array}$ \\
\hline
\end{tabular}




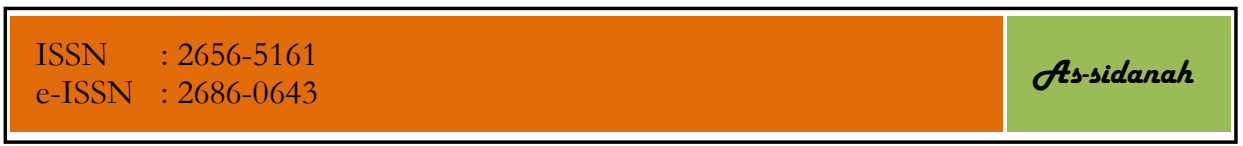

\begin{tabular}{|c|c|c|c|c|}
\hline No & $\begin{array}{c}\text { Nama } \\
\text { Pelaksana } \\
\text { PKM }\end{array}$ & Judul PKM & Relevasi kajian & Hasil \\
\hline & & & $\begin{array}{l}\text { pembelajaran Al } \\
\text { Qur'an Supaya } \\
\text { sistem } \\
\text { pembelajaran dan } \\
\text { penyajian sumber } \\
\text { pembelajaran } \\
\text { Yang dianut } \\
\text { sesuai dengan Al } \\
\text { Qur'an dan Hadis } \\
\text { dengan Melalui } \\
\text { beberapa } \\
\text { Tahapan-tahapan, } \\
\text { hal tersebut } \\
\text { ditempuh Melalui } \\
\text { Training Ustadz } \\
\text { dan } \\
\text { Ustadzah/masyara } \\
\text { kat dan tokoh } \\
\text { masyarakat, } \\
\text { selanjutnya, } \\
\text { Melalui } \\
\text { Pembinaan Santri } \\
\text { Ditempuh melalui } \\
\text { temu santri, Tabliq } \\
\text { Akbar dan Out } \\
\text { Bond FKPA } \\
\text { membina Unit }\end{array}$ & $\begin{array}{l}\text { n TPA di } \\
\text { randu sari } \\
\text { disampaiak } \\
\text { an Materi } \\
\text { Pokok yaitu } \\
\text { Bacaan, baca } \\
\text { Tulis Al } \\
\text { Qur'an } \\
\text { Hafalan } \\
\text { Dan Do'a } \\
\text { serta } \\
\text { diberikan } \\
\text { teori } \\
\text { tambahan } \\
\text { sesuai } \\
\text { kemapuan } \\
\text { Unit TPA } \\
\text { yaitu: } \\
\text { Aqidah } \\
\text { Akhlaq, } \\
\text { Fiqih dan } \\
\text { Sirah, } \\
\text { sedangkan } \\
\text { dalam } \\
\text { belajar Al } \\
\text { Qur'an } \\
\text { menggunak }\end{array}$ \\
\hline
\end{tabular}

Vo1. 2 No. 1, April 2020 Hosaini| 169 Zurnal Pengabdian Masyarakat 


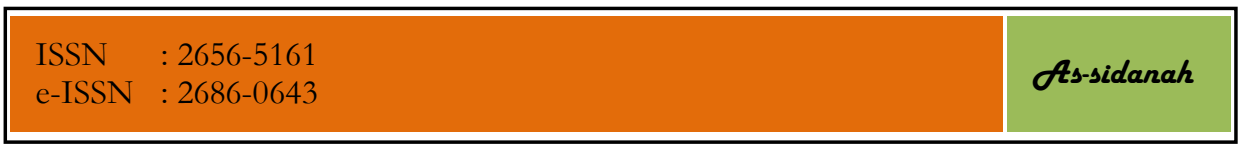

\begin{tabular}{|c|c|c|c|c|}
\hline No & $\begin{array}{c}\text { Nama } \\
\text { Pelaksana } \\
\text { PKM }\end{array}$ & Judul PKM & Relevasi kajian & Hasil \\
\hline & & & $\begin{array}{l}\text { TPA yang ada Di } \\
\text { Desa Randu Sari } \\
\text { dilakukan dengan } \\
\text { pendekatan } \\
\text { pembinaan Secara } \\
\text { langsung. }\end{array}$ & $\begin{array}{l}\text { an Iqro' } \\
\text { untuk } \\
\text { menyampai } \\
\text { akan teori } \\
\text { pembelajara } \\
\text { n Al Qur'an } \\
\text { dengan } \\
\text { Menggunak } \\
\text { an Beberapa } \\
\text { Metode } \\
\text { yaitu } \\
\text { Metode } \\
\text { Hiwar Kisah } \\
\text { Keteladana, } \\
\text { Pembiasaan } \\
\text { Targhib dan } \\
\text { Tarhib. }\end{array}$ \\
\hline 3 & $\begin{array}{l}\text { Nur Hayati } \\
\text { Tine MHI } \\
\text { dan Yaqop } \\
\text { Walangadi }\end{array}$ & $\begin{array}{l}\text { “Pembinaan } \\
\text { Karakter Bagi } \\
\text { Karang Taruna } \\
\text { Desa } \\
\text { Rejonegoro } \\
\text { Melalui CROSS } \\
\text { Curtural } \\
\text { learning ( Suatu } \\
\text { Pendekatan }\end{array}$ & $\begin{array}{l}\text { PKM yang } \\
\text { dilaksnakan Oleh } \\
\text { "Nur Hayati Tine } \\
\text { MHI dan Yaqop } \\
\text { Walangadi" } \\
\text { Mendiskripsikan } \\
\text { tentang Hilangnya } \\
\text { Nilai-Nilai Luhur } \\
\text { yang melekat }\end{array}$ & $\begin{array}{l}\text { Hasil dari } \\
\text { pelasanaan } \\
\text { PKM yang } \\
\text { dilaksanaka } \\
\text { n Oleh Nur } \\
\text { Hayati Tine } \\
\text { bersifat } \\
\text { Perencanan } \\
\text { dan }\end{array}$ \\
\hline
\end{tabular}




\begin{tabular}{|c|c|c|c|c|}
\hline No & $\begin{array}{c}\text { Nama } \\
\text { Pelaksana } \\
\text { PKM }\end{array}$ & Judul PKM & Relevasi kajian & Hasil \\
\hline & & $\begin{array}{l}\text { Pendidikan } \\
\text { Agama dan } \\
\text { Kearifa Budaya } \\
\text { Lokal })^{4}\end{array}$ & $\begin{array}{l}\text { pada generasi } \\
\text { Muda Kita, seperti } \\
\text { kejujuran } \\
\text { keantunan Dan } \\
\text { kebersamaan sa;ah } \\
\text { satu Upaya kea } \\
\text { rah itu adalah } \\
\text { Memperbaiki } \\
\text { Karakter generasi } \\
\text { Mudah Melalui } \\
\text { wadah organisasi } \\
\text { Pemuda yang ada } \\
\text { di Desa yaitu } \\
\text { karang taruna. } \\
\text { Target yang ingin } \\
\text { dicapai sebagai } \\
\text { berikut a. } \\
\text { Mentransfer Ilmu } \\
\text { pengetahuan Baru } \\
\text { dimasyarakat } \\
\text { yang aman } \\
\text { pengabdian ini } \\
\text { Mahasiswa lebih }\end{array}$ & $\begin{array}{l}\text { Pelaksanaan } \\
\text { yang masih } \\
\text { berbentuk } \\
\text { antisipasi } \\
\text { mencegah } \\
\text { pola fikir } \\
\text { masyarakat } \\
\text { yang } \\
\text { radikal, } \\
\text { Diantara } \\
\text { hasil } \\
\text { sosialisasi } \\
\text { dalam } \\
\text { pelaksanaan } \\
\text { ' perencanaa } \\
\mathrm{n} \\
\text { pembetukan } \\
\text { karakter } \\
\text { masyarakat } \\
\text { yang ada di } \\
\text { Desa } \\
\text { tersebut }\end{array}$ \\
\hline
\end{tabular}

4. Nur Hayati Tine. Pembinaan Karakter Bagi Karang Taruna Desa Rejonegoro Melalui CROSS Curtural learning ( Suatu Pendekatan Pendidikan Agama dan Kearifa Budaya Lokal) 2016 


\begin{tabular}{|c|c|c|c|c|}
\hline No & $\begin{array}{c}\text { Nama } \\
\text { Pelaksana } \\
\text { PKM }\end{array}$ & Judul PKM & Relevasi kajian & Hasil \\
\hline & & & $\begin{array}{l}\text { inovasi dalam } \\
\text { Mengeksplorasi } \\
\text { Sumber ilmu } \\
\text { pengethuan, dan } \\
\text { Pendidikan b. } \\
\text { mendorong } \\
\text { peningkatan } \\
\text { Partisiapsi dan } \\
\text { Pemberdayaan } \\
\text { generasi Muda } \\
\text { Khususnya Dan } \\
\text { Masyarakat } \\
\text { umumnya yang } \\
\text { ada di Desa } \\
\text { Rejonegoro untuk } \\
\text { selalu menjadi } \\
\text { terdepan dalam } \\
\text { kegiatan Positif } \\
\text { dan mengajak } \\
\text { orang lain untuk } \\
\text { sama- sama } \\
\text { memahami ajaran } \\
\text { agama dan } \\
\text { melestarikan } \\
\text { Budaya yang ada. } \\
\text { Dengan demikian } \\
\text { budaya toleransi }\end{array}$ & $\begin{array}{l}\text { sebagai } \\
\text { Berikut; } \\
\text { a. Masyarak } \\
\text { at yang } \\
\text { dibina } \\
\text { dalam } \\
\text { pembent } \\
\text { ukan } \\
\text { karakter } \\
\text { 100\% } \\
\text { mengadir } \\
\text { i acara } \\
\text { seminar, } \\
\text { dalam } \\
\text { pelaksana } \\
\text { an } \\
\text { kegiatan } \\
\text { seminar } \\
\text { ini, } \\
\text { masyarak } \\
\text { at } \\
\text { diberikan } \\
\text { kesempat } \\
\text { an untuk } \\
\text { melakuka } \\
\text { n diskusi } \\
\text { dengan }\end{array}$ \\
\hline
\end{tabular}




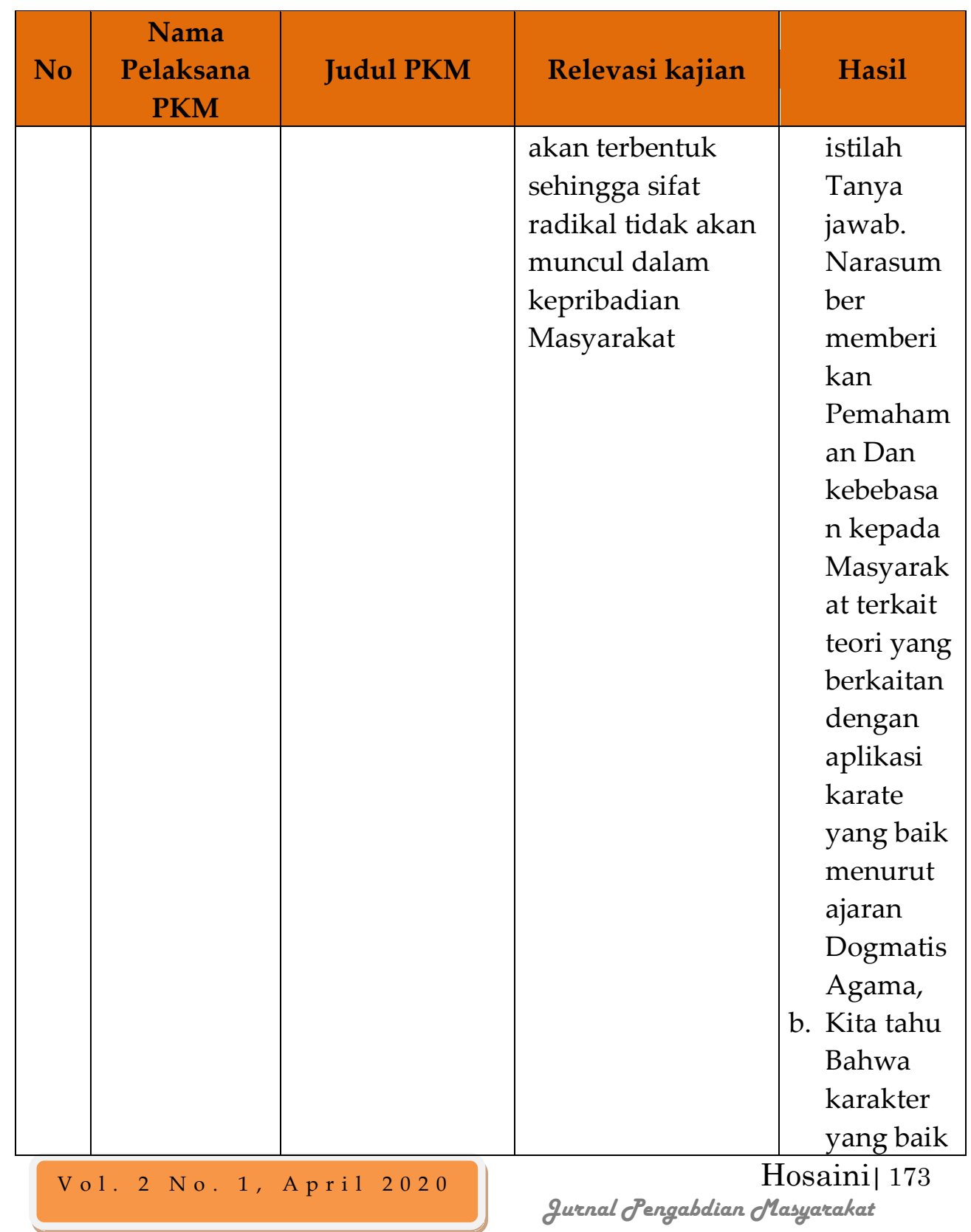




\begin{tabular}{|l|l|l|l|l|}
\hline No & $\begin{array}{c}\text { Nama } \\
\text { Pelaksana } \\
\text { PKM }\end{array}$ & Judul PKM & Relevasi kajian & Hasil \\
\hline & & & adalah \\
& & & metafora \\
& & yang \\
& & sangat \\
& & Fundame \\
& & lyang \\
& & harus \\
& & dimilin \\
& & oleh \\
& & masyarak \\
& & at agar \\
& & hidup \\
& & m,enjadi \\
& & makmur \\
& & arif dan \\
& & bijaksana \\
\hline
\end{tabular}

Dari 3 PKM yang di paparkan diatas dapat dijadikan Rujukan Pelaksanaan PKM yang akan saya laksanakan sebagai bentuk pengabdian kepada masyarakat, dengan Tema" Ngaji Sosmed Tangkal Pemahaman Radikal Melalui Pendampingan Komunitas Lansia Dengan Sistem Program Ngabari Di Desa Sukorejo Sukowono Jember" PKM yang akan saya laksanakan ini bersifat menagkal pemahaman Radikal yang terjadi desa sukorejo sukowono lantaran kebiasaan Masyarakat Mengaji Sosmed dengan menonton You Tube sehingga masyarakat belajar tidak bertahap dan salah menyimpulkan, efek dari semua itu adalah mebenarkan diri sendiri dan menyalahkan Orang lain. 


\section{Konsep Teori Pengabdian yang Relevan}

\section{Pengertian Media}

Media soasila adalah media yang mewadahi kerja sama diantara Pengguna yang menghasilkan konten(user generated content) sedangkan Dalam Kamus Besar Bahasa Indonesia, penggunaan memiliki arti proses, cara perbuatan memakai sesuatu, atau pemakaian Penggunaan merupakan kegiatan dalam menggunakan atau memakai sesuatu seperti sarana atau barang. Menurut Ardianto dalam bukunya yang berjudul Komunikasi Massa, tingkat penggunaan media dapat dilihat dari frekuensi dan durasi dari penggunaan media tersebut. 5

Menurut Lometti, Reeves, dan Bybee penggunaan media oleh individu dapat dilihat dari tiga hal, yaitu:

a. Jumlah waktu, hal ini berkaitan dengan frekuensi, intensitas, dan durasi yang digunakan dalam mengakses situs;

b. Isi media, yaitu memilih media dan cara yang tepat agar pesan yang ingin disampaikan dapat dikomunikasikan dengan baik.

5 Mandibergh. 2012. Hubungan Intensitas Mengakses Sosial Media terhadap Perilaku Belajar Mata Pelajaran Produktif pada Siswa Kelas XI Jasa Boga di SMK N 3 Klaten. Dalam Yuzi Akbari Vindita Riyanti (2016). Skripsi. Yogyakarta: Pendidikan Teknik Boga FT Universitas Negeri Yogyakarta. 
c. Hubungan media dengan individu dalam penelitian ini adalah keterkaitan pengguna dengan media sosial .

Media sosial sendiri didefinisikan sebuah media online, dengan para penggunanya bisa dengan mudah berpartisipasi, berbagi, dan menciptakan isi meliputi blog, jejaring sosial, wiki, forum dan dunia virtual. Blog, jejaring sosial dan wiki merupakan bentuk media sosial yang paling umum digunakan oleh masyarakat di seluruh dunia. Andreas Kaplan dan Michael Haenlein mendefinisikan media social sebagai "sebuah kelompok aplikasi berbasis internet yang membangun di ideologi dan teknologi Web 2.0, dan yang memungkinkan penciptaan dan pertukaran user-generated content

Media sosial adalah media online yang mendukung interaksi sosial. Sosial media menggunakan teknologi berbasis web yang mengubah komunikasi menjadi dialog interaktif. Beberapa situs media sosial yang populer sekarang ini antara lain : Blog, Twitter, Facebook, Instagram, Path, dan Wikipedia. Definisi lain dari sosial media juga di jelaskan oleh Van Dijk media sosial adalah platform media yang memfokuskan pada eksistensi pengguna yang memfasilitasi mereka dalam beraktivitas maupun berkolaborasi. Karena itu, media sosial dapat dilihat sebagai fasilitator online yang menguatkan hubungan 
antar pengguna sekaligus sebagai sebuah ikatan sosial.

\section{Ciri-Ciri Media Sosial}

Merebaknya situs media sosial yang muncul menguntungkan banyak orang dari berbagai belahan dunia untuk berinteraksi dengan mudah dan dengan ongkos yang murah ketimbang memakai telepon. Menurut mereka, pada dasarnya media sosial dapat dibagi menjadi enam jenis, yaitu :

Pertama, proyek kolaborasi website, di mana user-nya diizinkan untuk dapat mengubah, menambah, atau pun membuang konten-konten yang termuat di website tersebut, seperti Wikipedia.

Kedua, blog dan microblog, di mana user mendapat kebebasan dalam mengungkapkan suatu hal di blog itu, seperti perasaan, pengalaman, pernyataan, sampai kritikan terhadap suatu hal, seperti Twitter.

Ketiga, konten atau isi, di mana para user di website ini saling membagikan konten- konten multimedia, seperti e-book, video, foto, gambar, dan lain-lain seperti Instagram dan You tube.

Keempat, situs jejaring sosial, di mana user memperoleh izin untuk terkoneksi dengan cara membuat informasi yang bersifat pribadi, kelompok atau sosial sehingga dapat terhubung atau diakses oleh orang 
lain, seperti misalnya Facebook.

\section{Pengertian Masyarakat}

Masyarakat adalah golongan masyarakat kecil terdiri dari beberapa manusia, yang dengan atau karena sendirinya bertalian secara golongan dan pengaruh- mempengaruhi satu sama lain. ${ }^{6}$

Mayor Polak menyebutkan bahwa masyarakat adalah wadah segenap antar hubungan sosial terdiri atas banyak sekali kolektivakolektiva serta kelompok dalam tiap-tiap kelompok terdiri atas kelompok-kelompok lebih baik atau sub kelompok.

Sedangkan menurut Djojodiguno tentang masyarakat adalah suatu kebulatan dari pada segala perkembangan dalam hidup bersama antar manusia dengan manusia.

Konsep Masyarakat adalah arena dimaa praktek pekerjaan sosial makro beroprasi. Berbagai definisi mengenai masyarakat biasanya diterapkan berdasarkan konsep ruang, orang, interaksi dan identitas. Dalam arti sempit istilah masyarakat merujuk pada sekelompok orang yang tinggal dan berinteraksi yang dibatasi oleh wilayah geografis tertentu seperti desa, kelurahan, kampung atau rukun

${ }^{6}$ Hassan Shadily, 1983.Sosiologi untuk Masyarakat Indonesia. Penerbit: PT. Bina Aksara, Jakarta 
tetangga. Dalam arti luas, masyarakat menunjuk pada interaksi kompleks sejumlah orang yang memiliki kepentingan dan tujuan bersama meskipun tidak bertempat tinggal dalam satu wilayah geografis tertentu. Masyarakat seperti ini bisa disebut sebagai societas atau society. Misalnya, masyarakat ilmuwan, masyarakat bisnin, masyarakat global dan masyarakat dunia. ${ }^{7}$

\section{Suku bangsa (etnis)}

Komunitas etnis adalah:

Suatu konsep yang digunakan untuk menggambarkan sekumpulan manusia yang memiliki nenek moyang yang sama, ingatan sosial yang sama, dan beberapa elemen kultural. Elemen-elemen kultural itu adalah keterkaitan dengan tempat tertentu, dan memiliki sejarah yang kurang lebih sama. Kedua hal ini biasanya menjadi ukuran bagi solidaritas dari suatu komunitas.

Sebuah kelompok suku bangsa akan sangat mudah dibedakan dengan kelompok suku bangsa lainya, hal ini dikarenakan adanya keidentikan dari sebuah suku yang ada dan hal ini juga menjadi identitas pribadi bagi pemilik suku tersebut Rasa kebanggaan tersendiri

7 Suharto, Edi. 2006. Membangun Masyarakat Memberdayakan Rakyat. Bandung: Rafilka Aditama 
ketika seseorang tersebut memiliki suku bangsa itu, hal ini merupakan fitrah yang tidak bisa dirubah yang telah diberikan oleh Sang Pencipta kepada Umatnya.

\section{Pengertian Radikalisme}

Radikalisme merupakan paham atau aliran yang mengingikan perubahan atau pembaharuan sosial dan politik dengan cara kekerasan atau drastis. Esensi radikalisme adalah konsep sikap jiwa dalam mengusung perubahan. Sementara itu Radikalisme Menurut Wikipedia adalah suatu paham yang dibuat-buat oleh sekelompok orang yang menginginkan perubahan atau pembaharuan sosial dan politik secara drastis dengan menggunakan cara-cara kekerasan. Apabila dilihat dari sudut pandang keagamaan dapat diartikan sebagai paham keagamaan yang mengacu pada fondasi agama yang sangat mendasar dengan fanatisme keagamaan yang sangat tinggi, sehingga tidak jarang penganut dari paham/aliran tersebut menggunakan kekerasan kepada orang yang berbeda paham/aliran untuk mengaktualisasikan paham keagamaan yang dianut dan dipercayainya untuk diterima secara paksa.

Adapun yang dimaksud dengan radikalisme adalah gerakan yang berpandangan kolot dan sering menggunakan kekerasan dalam 
mengajarkan keyakinan mereka. Sementara Islam merupakan agama kedamaian.

\section{Islam dan Radikalisme}

Sebagaimana dijelaskan sebelumnya, bahwa Islam merupakan ketundukan seorang hamba kepada wahyu Ilahi yang diturunkan kepada para nabi dan rasul khususnya Muhammad SAW guna dijadikan pedoman hidup dan juga sebagai hukum/aturan Allah SWT yang dapat membimbing umat manusia ke jalan yang lurus, menuju ke kebahagiaan dunia dan akhirat

Menurut Yusuf Qardhawi Radikalisme adalah sikap berebihan yang seseorang miliki dalam beragama, ketidak sesuaian antara akidah dengan prilaku, antara yang seharusnya dengan realitas, antara agama dengan politik, antara ucapan dengan tindakan, antara yang diangankan dengan yang dialaksanakan, serta antara hukum yang di syaratkan oleh Allah dengan produk hukum manusia itu sendiri

\section{Metode dan Teknik Pengabdian}

Tabel 1. Tahapan dan Kegiatan "NGABARI" -Pengabdian di Desa Sukorejo Sukowono Jember. 


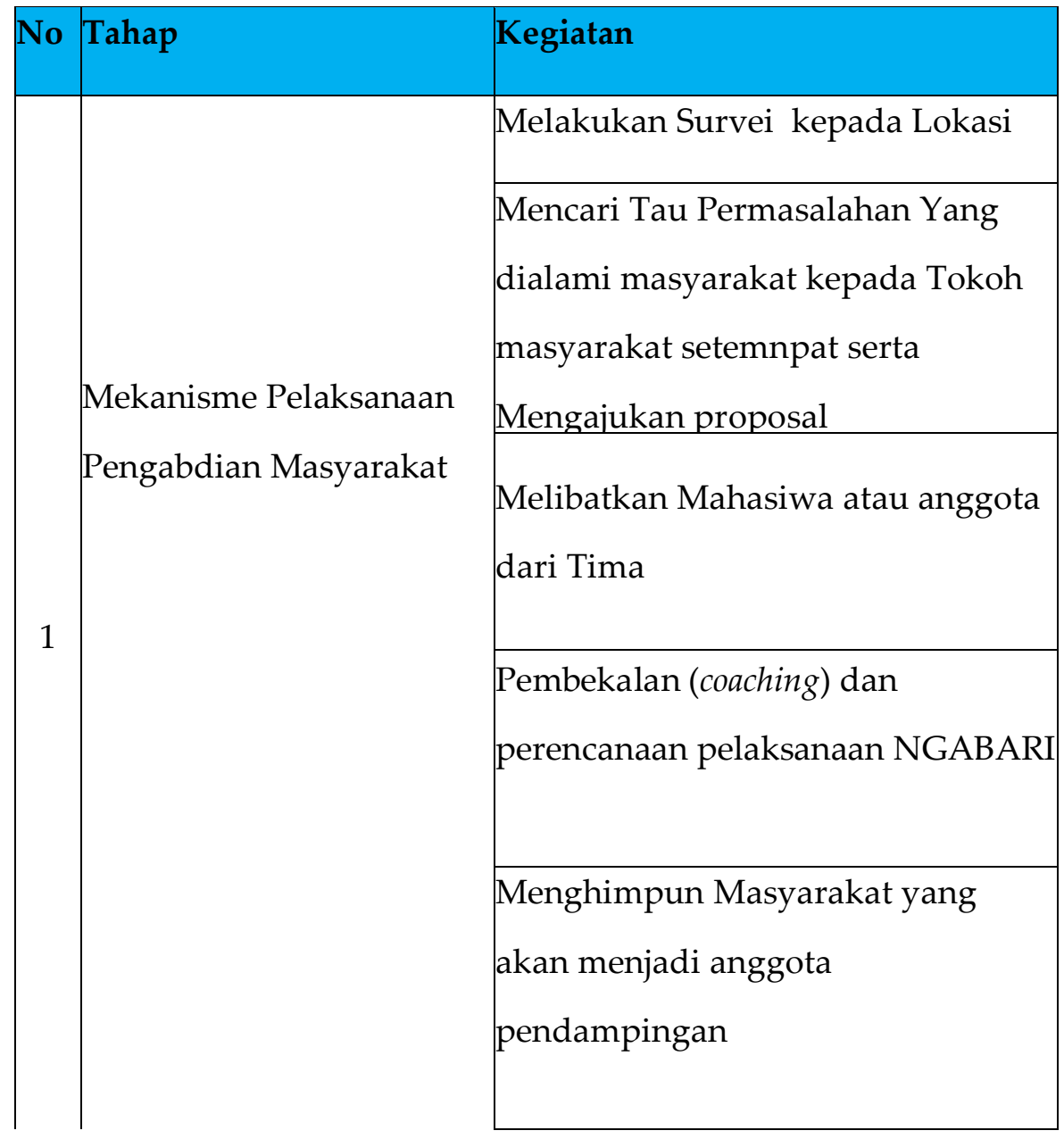




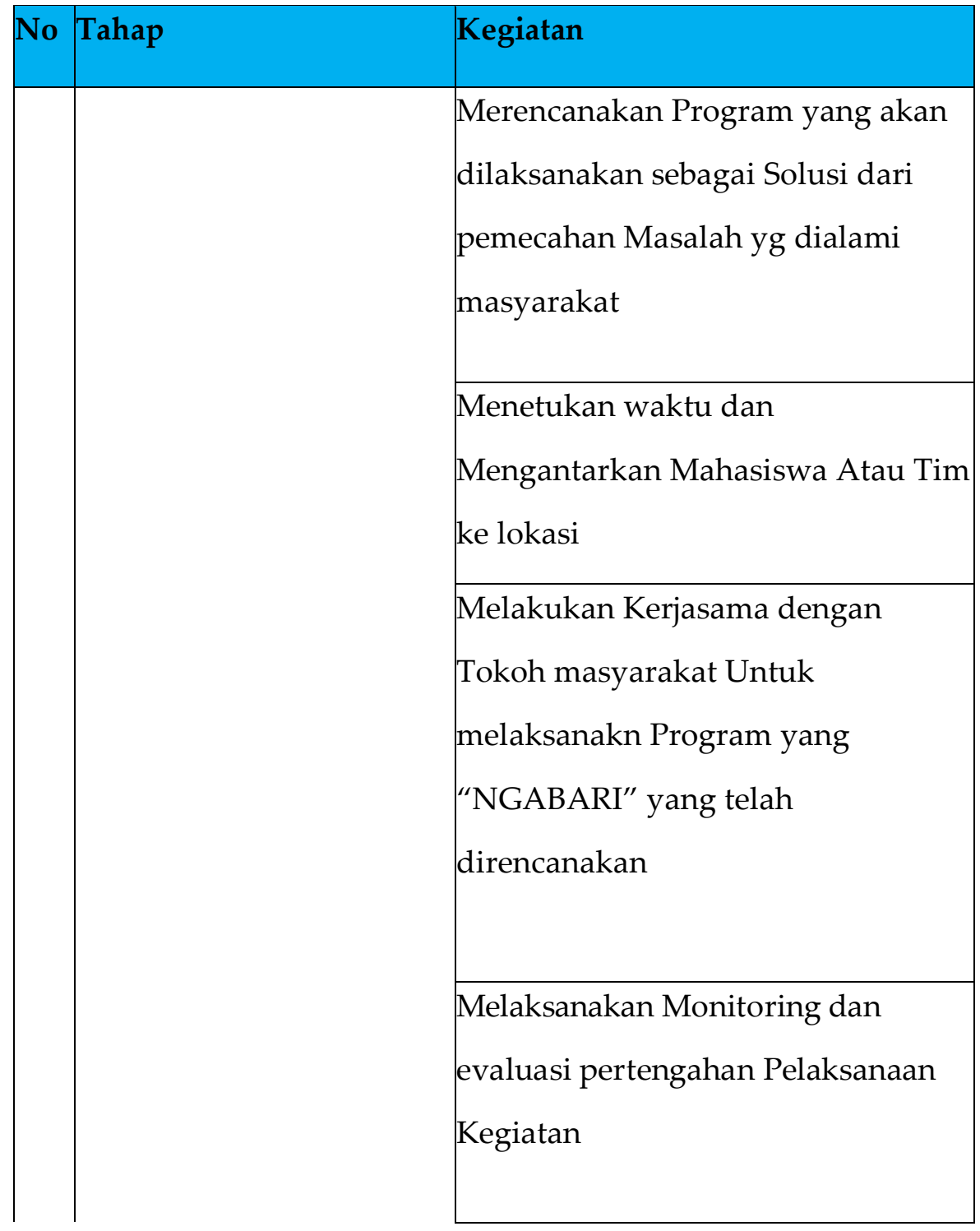




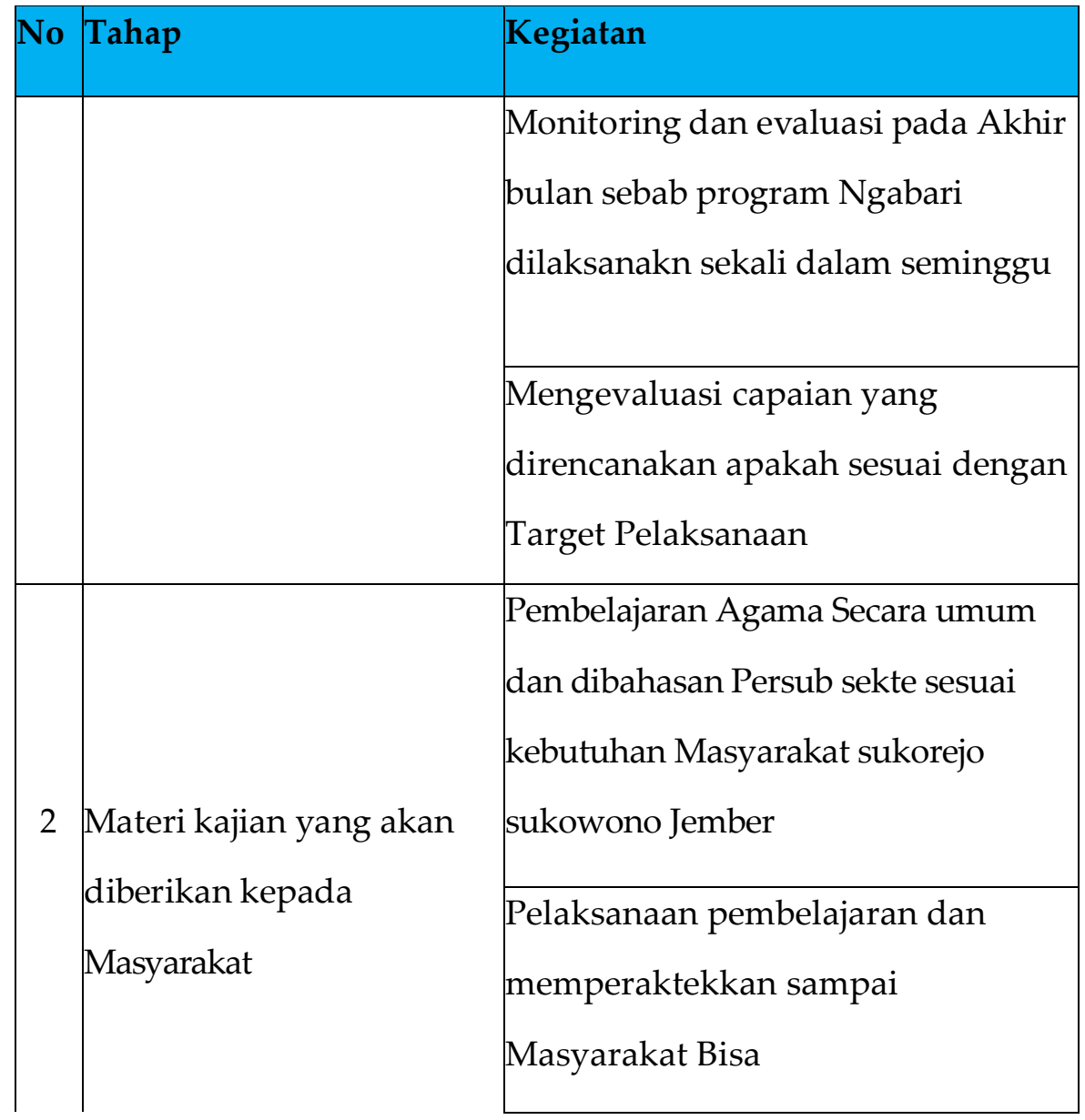




\begin{tabular}{|c|c|}
\hline No Tahap & Kegiatan \\
\hline & $\begin{array}{l}\text { Pembinaan yang dilakukan Kepada } \\
\text { Masyarakat untuk mengembalikan } \\
\text { pola fikir masyarakat sesuai dengan } \\
\text { ajaran dan kaidah yang } \\
\text { berlandaskan Al Qur'an dan Hadits }\end{array}$ \\
\hline
\end{tabular}

\section{Pelaksanaan}

Langkah-langkah dalam pelaksanaan bentuk Program "NGABARI" akan dilaksnakan dilokasi pengabdian melipiti hal-hal sebagai berikut yaitu program pendampingan Melalui Pengajaran keagamaan sesuai dengan Aliran Ahlusunnah Waljama'ah, pelaksnaan praktek secara langsung, memberikan Bimbingan Dan arahan kepada Masyarakat Terkait pentinggnya mencari Guru agama dari pada Belajar Kepada You Tube Mengevaluasi pelaksanaan program Kegiatan setia satu bulan satu kali dan menindak lanjuti hasil evaluasi

Metode yang digunakan Dalam pelaksnaan Program sistem pendampingan dengan menyajikan pembelajaran berbasis sumber $\mathrm{Al}$ Qur'an Hadist sebagai Rutinitas pelaksanaan kegiatan Keagamaan masyarakat maupun Yang lainnya.selain itu, juga kami menyajikan 
teori-teori yang berkaitan dengan kebutuhan Masyarakat serta meberikan Peraktek secara langsung dalam Pelaksanaan Kegiatan Pengabdian Masyarakat.terkait dengan langkah Langkah Operasional yang diperlukan untuk mengatasi permasalahan seperti pada tujuan dari pengabdian ini adalah seperti;

a. Bagaimana strategi mengatasi pola fikir masyarakat yang radikal sebab pel;antara kebiasaan Menonton you tube sebagai dasar pembelajaran Agama sialam.

b. Program yang akan direncanakan Oleh kami sebagai Pelaksana Pengabdian, akan selalu dikordinasikan kepada tokoh masyarakat sebagai metra pelaksanaan dan implementasi Ilmu agama kepada masyarakat .

c. Pelaksanaan PKM menjadi prihal yang baru di desa sukorejo memilih, target minimal masyarakat yang kami bina adalah menjadi masyarakat yang konstruktif dan produktif d. pelaksanaan kegiatan disertai dengan sistem Tanya Jawab dan prektek secara langsungMengimplementasikan Pembelajaran sesuai kebutuhan Masyarakat

\section{Rencana Pengabdian}

Pengabdian ini akan dilaksnakan di desa Sukorejo sukowono 
Jember jawa timur dan objek sasarannya adalah Masyarakat secara khusus dan Umum, adapun tempat pelaksananya di Pondok Online Pesantren Silat Rumah Tahfidz.

\section{Target Pengabdian}

Target Pengabdian kepada Masyarakat ini mengupayakan pelaksanaan Program Kegiatan yang direncanakan dapat terlaksna dengan baik, sesuai dengan waktu yang telah ditentukan

\section{Hasil}

Program ngabari yang dilaksankan oleh tokoh masyarakat bekerjasama dengan Dosen pendidikana Agama Islam, menghasilkan program kegiatan keagamaan yang dikemas dengan istilah program kegiatan "NGABARI" ngaji bareng, kegiatan ini, dilaksanakan sebagai rutinitas kegiatan keagamaan masyarakat di desa sukorejo sukowono jember, pelaksanaannya setiap 1 bulan satu kali, selama satu Tahun,

Diantara hasil yang didapatkan adalah meningkatnya kompetensi pembelajaran keagamaan masyarkat, dengan adanya program ini, mampu meluruskan pemahaman masyarakat yang kontradiktif terhadap esensi pembelajaran agama islam secara dasar. Faham keagamaan masyarakat yang radikal, sebab ngaji sosmed dapat terstepis dengan kegiatan program "ngabari" sebagaimana dalam pelaksanaan 
program ngabari, masyarakat diberikan sajian pembelajran keagamaan dan diberikan kesempatan untuk bertanya.

\section{Kesimpulan}

Masyarakat Desa Sukurejo Sukowono Jember adalah masyarakat yang masih tergolong Agraris dalam artian masyaraktat agraris merupakan masyarakan yang bergerak disektor pertaniaan atau penduduk mayoritas mata pencahariannya dibidang sector Pertanian, Pola hidup masyarakat dimasing-masing Desa Memang berbeda-beda. Dimensi kehidupan Masyarakat Ada 3 a. Masyarakat Dinamis b. Masyarakat Agraris dan Masyarakat Pesisir, seperti apapun intensitas dan kondisi Masyarakat adalah kehidupan yang bersifat Sunnatullah, namun Masyarakat Yang baik adalah Masyarakat yang memiliki pola kehidupan yang harmonis mempunyai Sifat Toleransi cinta Tanah Air, memiliki Sifat Nasionalisme,

Simpati dan empati terhadap Sesama. Diantara hasil yang didapatkan adalah meningkatnya kompetensi pembelajaran keagamaan masyarkat, dengan adanya program ini, mampu meluruskan pemahaman masyarakat yang kontradiktif terhadap esensi pembelajaran agama islam secara dasar. Faham keagamaan masyarakat yang radikal, sebab ngaji sosmed dapat terstepis dengan kegiatan 
program "ngabari" sebagaimana dalam pelaksanaan program ngabari, masyarakat diberikan sajian pembelajran keagamaan dan diberikan kesempatan untuk bertanya.

\section{Daftar Pustaka}

UUD No. 28 Tahun 2006

Taufiqurrahamn DKK. Laporan Kegiatan Pengabdian Kepada Masyarakat "pelatihan khotib dan Bilal dikecamatan Uya Kabupaten tabalong 2014.

Sunarimo. Pendampingan Forum komonikasi Pendidikan Al Qur'an ( dalam pembinaan Taman Pendidikan Al Qur'an) 2011.

Nur Hayati Tine. Pembinaan Karakter Bagi Karang Taruna Desa Rejonegoro Melalui CROSS Curtural learning ( Suatu Pendekatan Pendidikan Agama dan Kearifa Budaya Lokal) 2016.

Hosaini Annaba' Implementasi Media Pembelajaran Volume 32017.

Depdiknas RI, Kamus Besar Bahasa Indonesia, (Jakarta : Balai Pustaka, 2002.

Ardianto Elvinaro, Komunikasi Massa : Suatu Pengantar, Bandung : Simbiosa Rekatama

Media, Thea Rahmani, Penggunaan Media Sosial Sebagai Penguasaan Dasar-Dasar Fotografi Ponsel, Universitas Islam 
Negeri Sunan Kalijaga Yogyakarta, 2016.

Michael Haenlein, Users of the world, unite! The challenges and opportunities of Social Media". Business Horizons, 2010.

Rulli Nasrullah, Media Sosial : Perspektif Komunikasi, Budaya, dan Sosioteknologi, (Bandung : Remaja Rosdakarya, 2017.

Tim pusat Perdagangan RI Pandua Optimalisasi Media Sosial Untuk Kementrian Perdanganan RI (Jakarta, Pusat Humas Kementrian Perdagangan RI:2014.

Hosaini Devebloment basid learning Perspektif Al Ghazali tahun 2018. Kartono, kartini Pengantar Metodelogi Risets bandung Alumni 1995 Burhan Bungin, Metodologi Penelitian Sosial: Format-format Kuantitatif dan Kualitatif, Surabaya: Airlangga University Press, 2001.

Yusuf Qardlawi Islam Radikal analisis terhadap Radikalisme dama berislam dan upaya Pemecahannya ,solo Era Intermadia, 2014. 